\section{O contrato administrativo}

Vandeli Rohsig Dannebrock

Mestranda em Direito pela Universidadde Federal do Rio Grande do Sul

\section{SUMÁRIO}

Introdução; I - Diferentes correntes doutrinárias a respeito do contrato administrativo; I. a - Corrente negativista; I. b - Corrente que admite a existência de contratos administrativos distintos dos contratos regidos pelo direito privado; I. c - Corrente que entende que todos contratos administrativos são regidos pelo direito público; II Peculiaridades do contrato administrativo; II a - Prerrogativa da administracáo; Il b - O equlibrio econômico -financeiro; II. c - Aplicabilidade das teorias da imprevisão e da base de negócio jurídico; Conclusão.

\section{Abstract}

The paper develops some ideas on the admin different juridical-doctrinal approaches to the admissibility of the administrative contract for conjugating concepts otherwise originally antag onistic: on one side the figure of the contract, the consecrator of the individual will, and of the equality between the contracting parties; and on the other side, the juridical regime of public law, the consecrator of the public concern over the individual one, and the position of supremacy of the Public Administration. It still exposes the positions of the main doctrines around the ques tion of the juridical regime to which are subordinate the administrative contracts and the criteria utilized for such.

On a second part it analyzes the peculiarities of the administrative contract, especially: the prerogatives of Public Administration as expressed by the existence of exorbitant provisions and by the power of unilateral modification of the administrative contract; the economic-financial balance which must be preserved during the whole execution of the contract; the applicability of improvidence theories and of the basis of the juridical business to administrative contracts.

\section{Introdução}

O conceito tradicional do contrato alicerça-se na horizontalidade ou igualdade das partes contratantes, na liberdade da maistrative contract. It deals initially with the nifestação da vontade e na imutalidade do avençado, o qual faz lei entre as partes.

Por outro lado, pedra angular do direito jurídico de direito público, derrogatório e exorbitante do direito comum, ou, em outras palavras, a consagração do princípio d predominância do interesse público sobre o interesse individual.

Como conciliar, portanto, a noção de contrato administrativo, regido primordial mente pelo direito público com a noção paralela do contrato tradicional?

A perplexidade que impede ou impediu a completa e imediata aceitação da figura do contrato administrativo reside exatamente na contradição existente entre a concepção tradicional de contrato em contraposição com uma modalidade de contrato onde se vêem consagradas as cláusulas exorbitantes, as quais são consideradas como derrogadoras da imutabilidade, da igualdade entre as partes.

Entretanto, hoje se põe em questão até mesmo a existência da divisão secular entre o Direito Público e o Direito Privado, afirmando-se que inexistem "secções" na Ciência Jurídica.

Assim, o contrato administrativo, apesar de suas peculiaridades em virtude de estar o Estado em um dos pólos da relação jurídica, deve ser visto, antes de mais nada, como Contrato.

Por outro lado, como observa Orlando Gomes", "no curso deste século, o consenadministrativo é a sua sujeição ao regime sualismo ou voluntarismo vai sendo misturado com fatores estranhos e perdendo, em conseqüência, a sua condição de nota característica do contrato. $\mathrm{Na}$ crista de importantes mudanças, o Estado entra em cena e se passa das situações voluntárias (consentidas), que os interessados escolhem, para o estatuto imposto, surgindo figuras de duvidoso caráter contratual, tais como o contrato normativo, o contrato coativo, o contrato padrão e o contrato de adesão". Assim, através do dirigismo contratual se busca restabelecer o equilíbrio contratual quando uma das partes é economicamente mais fra$\mathrm{ca}$, determinando em que termos certos objetos podem ser contratados, como ocorre em matéria trabalhista ou de locações.

Por fim, também o princípio da obrigatoriedade das convenções encontra restrições pela possibilidade de liberação ou de revisão das obrigações quando, na execução do contrato, as condições se alteram significativamente em relação à época da primitiva estipulação. É o caso da cláusula rebus sic stantibus, da teoria da imprevisão, da "teoria da força maior", as quais excepcionam o princípio da obrigatoriedade das convenções.

Analisando algumas destas questões, abordaremos neste trabalho, numa $1 \underline{\underline{a}}$ parte, as principais correntes a respeito do contrato administrativo e, numa $2^{\underline{a}}$ parte, as principais peculiaridades inerentes a esta categoria jurídica.

\section{I - Diferentes correntes a respeito do} contrato administrativo

\section{a. Corrente negativista}

É a corrente aceita especialmente na Alemanha e na Itália ${ }^{2}$.

Os principais argumentos da tese negativista, sintetizados por Osvaldo A. B. de Mello, são: ${ }^{3}$

a) impossibilidade de celebração de contrato entre pessoas de situação jurídica distinta, dada a posição de supremacia da Administração Pública diante dos administrados; b) sobre o objeto do contrato, uma vez que as obras e serviços públicos e os bens a que ele se refere estarem fora do comércio; ge autonomia da vontade e vinculação às suas cláusulas as quais fazem lei entre as partes, o que não se coaduna com o interesse público que muitas vezes exige a alteração do contrato para a ele se adaptar. Por outro lado, exige que o administrado adira ou não ao contrato, não podendo negociar livremente suas cláusulas ${ }^{4}$.

Principal expoente da corrente negativistas foi Otto Mayer, que afirmava que "o Estado sempre manda unilateralmente" ${ }^{5}$ e que, portanto, o contrato administrativo violaria o princípio da igualdade, pois "seria um procedimento lindante com o arbítrio regular uma situação geral não por intermédio de uma norma jurídica mas por intermédio de contratos diferenciados com os interessados, com o que seria inevitável que o mais forte levasse a maior parte" $6,7,8$.

$\mathrm{Na}$ Alemanha os contratos celebrados com a administração pública são, em sua maioria contratos de direito privado'. O contrato de concessão de serviço público, o contrato de fornecimento, de construção de obras públicas são tidos todos como contratos de direitos privado.

$\mathrm{O}$ que modernamente se entende como contratos administrativos na doutrina alemã são algumas novas formas de administração, que necessitam da colaboração dos administrados para a realização de medidas que outrora eram realizadas unilateralmente por atos administrativos, como por exemplo, em alguns casos, as licenças para construção ou nos acordos sobre o valor da indenização em caso de desapropriação ${ }^{10}$.

A mesma linha segue dominantemente a doutrina italiana ${ }^{11}$.

b. Corrente que admite a existência de contratos administrativos distintos dos contratos re gidos pelo direito privado.

$\mathrm{O}$ direito brasileiro admite a existência te particular, a doutrina francesa. c) sobre a natureza do contrato, que exide contratos administrativos, seguindo nes- 
No direito francês, a existência de contratos administrativos distintos dos contratos regidos pelo direito privado, numa distinção inicial, surge como uma exceção ao esquema estrutural atos de autoridade - atos de gestão, chamada primeira sistematização do Direito Administrativo; neste - e na jurisdição contencioso-administrativa - se integram os atos ditados imperativamente pela Admistração, enquanto que esta prescinde do imperium e se submete aos modos de gestão do Direito privado; é este último que rege sua atuação, submetendo-se correlativamente aos tribunais ordinários. $\mathrm{O}$ contrato se considera então como o tipo mesmo dos atos de gestão, isto é, daquelas atuações que a Administração realiza despojada de imperium, descendo ao nível dos particulares e em igualdade com eles, não obstante o qual, por razões pragmáticas, de simples utilidade (não por razões dogmáticas) se atribui o conhecimento de alguns dos contratos que a Administração celebra à jurisdição contencioso-administrativa ${ }^{12}$.

$O$ que ocorre é que por razões de utilidade prática, isto é, por serem os tribunais administrativos mais rápidos e conhecerem melhor as questões atinentes à Administração Pública é que estes são submetidos à jurisdição contencioso-administrativa ${ }^{13}$

A distinção inicial se refere, pois, apenas ao regime jurisdicional, não afetando a sua natureza nem a sua regulação de fundo, que seguem sendo as próprias de toda questão civil.

Somente no século $\mathrm{XX}$ é que se faz a distinção de fundo, utilizando-se o critério material do serviço público ${ }^{14}$.

Desde o caso Blanco, o direito administrativo se desenvolve em torno do conceito de serviço público, que fixa a linha divisória entre a competência da justiça comum e da justiça administrativa e a separação do direito administrativo e do direito privado.

Coube a Jèze, como chefe de escola de Bordéus ${ }^{15}$ ou do Serviço Público, desenvolver a teoria dos contratos administrativos. Assim, se a relação jurídica estiver relacionada com a noção de serviço público e tiver em um dos pólos entidade que integra a
Administração Pública, ela será de direito administrativo; se faltar um destes pressupostos, a relação será de direito privado.

Posteriormente, a justificação de um regime jurídico especial aos contratos administrativos se fez por meios das cláusulas exorbitantes do direito comum. Por isto a derrubada do critério do serviço público e da repartição conseqüente de competências não produziu consigo a derrubada da distinção entre os contratos administrativos e os contratos de direito privado firmados pela Administração. Ou seja, como afirma Brewer-Carias ${ }^{16}$, "a distinção já havia adquirido substantivação e perdido sua base adjetiva, com suporte na idéia-chave das cláusulas exorbitantes de direito comum, as quais sempre estavam nos primeiros e não se encontram nos segundos".

Os critérios utilizados para caracterizar o contrato administrativo podem ser sintetizados da seguinte forma:

$1^{\circ}$ ) quando seu objeto for a execução de um serviço público;

$\left.2^{2}\right)$ quando o contrato contiver cláusulas exorbitantes do direito comum, ou

$\left.3^{\circ}\right)$ por determinação legal.

A estes se agrega, ainda, a necessidade de que figure num dos pólos pessoa jurídica de direito público. Este critério, entretanto, foi afastado pelo Tribunal de Conflitos no caso Peyrot C. Societe de L'Autoroute Esterel. Côte D'Azur, onde havia apenas a intervenção de um organismo de direito privado por conta do Poder Público, ou na realização de obra pública ${ }^{17}$.

No direito brasileiro, a noção do serviço público é relevante para a caracterização do contrato administrativo. Para assegurar a continuidade dos serviços públicos, não podem os particulares, como credores da administração, deixar de cumprir suas obrigações, mesmo que estes tenham seus direitos desrespeitados pelo Estado.

Neste sentido, afirma Cretella Jr.: ${ }^{18} 19$ "Não há dúvida de que, sob certos aspectos, os contratos administrativos se assemelham aos contratos celebrados pelos particulares entre si. O regime jurídico de um e outro, a uma análise superficial, é idêntico, mas isto apenas na aparência, porque um elemento essencial está presente nos contratos administrativos, elemento ausente dos contratos do direito comum: os contratos administrativos concluem-se para o funcionamento de serviço público".

O mesmo autor é adepto de tese de que há diferenças entre os contratos privados celebrados pela Administração e os contratos públicos, admimistrativos. Apontta ele: "nem todo contrato 'da' Administração é contrato administrativo, pois este é espécie daquele. É aquele quando submetido a determinado regime jurídico, que não é o direito comum ou de direito privado, mas regime especial; o regime jurídico de direito público, exorbitante e derrogatório de direito comum"20

Também neste sentido, Maria Sylvia Z. Di Pietro traça os pontos comuns e os traços distintivos entre os dois tipos de "contratos da Administracão": "Quando se cuida do tema contratual, verifica- se que, no que se refere às sujeições impostas à Administração, não diferem os contratos de direito privado e os administrativos; todos eles obedecem a exigências de forma, de procedimento, de competência, de finalidade; precisamente por essa razão é que alguns autores acham que todos os contratos $\mathrm{da}$ Administração são contratos administrativos".

"Já no que concerne a prerrogativas, as por meio das chamadas cláusulas exorbitantes ou de privilégio ou de prerrogativa".

"Outra diferença entre contrato administrativo e o contrato de direito privado da Administração, diz respeito ao objeto. $\mathrm{O}$ contrato administrativo visa à prestação de serviço público, não no sentido restrito de 'atividade exercida sob regime jurídico exorbitante', mas no sentido mais amplo, que abrange toda atividade que o Estado assume, por lhe parecer que a sua realização era necessária ao interesse geral, e que a iniciativa privada era insuficiente para realizar adequadamente. Abrange os serviços públicos comerciais e industriais do Estado que, embora exercidos, em geral, sob regime de direito privado, podem ter execução transferida a particular por meio do contrato de concessão de serviço público, que é o contrato administrativo por excelência"21.

c. Corrente que entende que todos os contratos da administrasãa são regidos pelo Direito Público.

É a tese defendida por autores como Gordillo, por Brewer-Carias e por Garcia de Enterria ${ }^{22}$. Afirma Brewer-Carias: "Não há, na realidade, atividades privadas da administração. Assim como não existem atos privados da Administração, tampouco existem, claramente, contratos privados da Administração" ${ }^{\prime 2}$.

$\mathrm{E}$, a seguir, complementa: "Em matéria de contratos da Administração, então, haverá contratos com um regime preponderante de direito administrativo ou preponderante de direito civil, ou se se quiser, haverá contratos nos quais a modulação administrativa alcança maior ou menor intensidade".

Para os autores adeptos desta corrente, as cláusulas exorbitantes são na realidade decorrentes dos próprios poderes de ação unilateral da Administração, como gestora do interesse público.

Além do mais, não existindo no Brasil uma repartição de jurisdições, à moda francesa, entendem os autores brasileiros que não há necessidade de tal distinção.

De qualquer forma, é certo que os contratos administrativos possuem traços característicos, que serão analisados na $2^{2}$ parte deste trabalho.

\section{II - Peculiaridades de contrato} administrativo

a. Prerrogativas da administraşão a.1. As cláusulas exorbitantes

Além dos elementos essenciais do contrato administrativo como a capacidade das partes $^{24}$, o objeto lícito e possível, o consentimento, o preenchimento das formalidades exigidas $^{25}$, o fim de interesse público e a presença da Administração como um dos sujeitos da relação jurídica, acrescenta-se a 
característica de dever possuir ele cláusulas exorbitantes ${ }^{26}$ do Direito comum ${ }^{27}$.

O conceito de serviço público, no direito brasileiro, desempenha papel importante para a identificação do ramo a que pertence determinado contrato, se ao direito privado ou ao direito público. Assim, os contratos realizados pelo Estado serão contratos administrativos sempre que estiverem vinculados a um serviço público ou persigam objeto de interesse imediatamente público contendo, ainda, cláusulas extravagantes do direito comum ${ }^{28}$.

Embora existam algumas opiniões divergentes $^{29}$, a maior parte da doutrina cita a presença de cláusulas exorbitantes como uma característica essencial do contrato administrativo ${ }^{30}$.

Assim Eduardo Soto Kloss, que afirma não passarem as cláusulas exorbitantes de um velho ranço medieval, importando nas contratações públicas não a simples adesão do particular, mas a relação jurídica contratual, o objeto de tal relação vinculado diretamente à organização e ao funcionamento dos serviços públicos ${ }^{31}$.

As cláusulas exorbitantes podem consignar as mais diversas prerrogativas, no interesse do serviço público. Representam, portanto, poderes da Administração de alteração e rescisão unilateral do contrato, fiscalização e controle de sua execução, aplicação de penalidades, inoponibilidade da exceção do contrato não-cumprido, que imprimem ao contrato administrativo, a marca do direito público.

9.2. Poder de modificaşão unilateral

Segundo Labaudère ${ }^{32}$, sintetizando os elementos da tese habitual, que vê no poder de modificação unilateral da administração um elemento da teoria geral dos contratos administrativos, estes se resumem da seguinte forma:

"a) o poder de modificação unilateral é considerado como sendo de ordem pública; a administração não pode renunciar, previamente, a exercê-lo (Jèze, ob. cit., pág. 225; Bonnard, ob. cit., pág. 620); b) o poder de modificação existente fora das estipulações do contrato, quando este último o prevê, não o criando, entretanto, e apenas regulando suas condições de exercício, particularmente seus limites e suas conseqüências pecuniárias (Jèze, ob. cit)"

Já em relação aos limites, afirma Labaudère ${ }^{33}$ : "Os limites do poder de modificação são de duas ordens:

de uma parte, as modificações unilaterais só podem afetar as cláusulas do contrato que interessem ao serviço público e às suas necessidades (isto é, as prestações do co-contratante e suas modalidades de execução), com exclusão das cláusulas que reguam as relações de interesse entre as partes (principalmente as cláusulas financeiras).

- por outro lado, a administração não pode utilizar o seu poder de modificação a ponto de impor ao contratante alterações excessivas, que ultrapassem um limite razoável, isto é, capazes de ocasionar a transformação do próprio objeto do contrato (por exemplo, transformar uma concessão de serviço público em uma régie disfarçada; ou exceder as possibilidades técnicas ou econômicas do co-contratante".

Mais recentemente, alguns autores têm ressaltado que o poder de modificação uniateral não é aplicável de forma uniforme a todos os contratos administrativos, sendo o mais peculiar o contrato de concessão de serviços públicos. Neste sentido, afirma Celso Antonio B. de Mello ${ }^{34}$ :

"Com efeito, na concessão de serviço, trespassa-se a um terceiro o exercício de uma atividade que é havida pelo Estado como essencial, ou seja, basilar, 'existencial à coletividade num momento dado', para usar a expressão de Duguit".

"Seu desempenho, então, envolve cometimentos absolutamente típicos do Estado, reclamam o exercício de poderes característicos e especificamente públicos e põe em causa atividades que não podem, sob aspecto algum, ser parificadas com empreendimentos privados, pois estão em jogo interesses transcedentes. É lógico, ademais, que estas atividades, uma vez iniciadas, não possam ser suprimidas abruptamente, nem pos- sam ser interrompidas ou suspensas, pena de causar gravíssimos transtornos..."

Por força destes aspectos, haveria a necessidade de distinguir as regras comuns aos contratos administrativos e aquelas próprias de certas espécies.

Afirma Labaudère ${ }^{35}$ :

"Nos contratos administrativos que não visem a uma participação direta do co-contratante no serviço público ou na obra pública, mas apenas a uma colaboração indireta, sob a forma de prestações destinadas a satisfazer as necessidades do serviço, é que a noção de um poder de modificação unilateral cessa de encontrar um fundamento preciso".

Já a rescisão unilateral pode ocorrer tanto por inadimplência do contratante (rescisão - sanção), como por interesse público na cessação da normal execução do contrato ${ }^{36}$.

Frente ao contratante, tem ainda a Administração o poder permanente de direção e controle dos contratos que celebra, supervisionando e intervindo na execução das prestações. Esta cláusula insere-se em qualquer contrato administrativo, de forma expressa ou implícita.

Como corolário deste princípio, dispõe a Administração do poder de aplicar penalidades contratuais ou outras sanções legais não previstas no ajuste, sem o que seria inócuo o acompanhamento da execução como nos casos de cessão não autorizada, execução imprópria, e em geral compreendem advertências, multas e até recisão unilateral pela Administração, além da suspensão provisória e da declaração de inidoneidade para contratar com a Administração. $\mathrm{O}$ regime especial das sanções constitui, para a autoridade administrativa, privilégio acentuado que se justifica pelo asseguramento dos serviços públicos. $\mathrm{Na}$ aplicação dessas penalidades, a Administração independe de prévia intervenção do Poder Judiciário, a não ser que o particular contratante ofereça resistência.

Por fim, é ainda por força do princípio superior da continuidade do serviço público que pode haver a derrogação do princí pio exceptio non adimpleti contractus, regra do art. 1092 do Código Civil, que autoriza suspensão da execução do contrato por uma das partes à inadimplência da outra. Isto é, o inadimplemento da Administração, na execução de suas prestações, não autoriza a suspensão da execução do contrato pelo particular contratante. Mas, se a falta é do particular, a exceptio é invocável pela Administração, em seu favor.

De acordo com Carlos Roberto Pellegrino ${ }^{37}$, também este princípio vem sofrendo atenuações de seus rigores, "já admitindo a doutrina mais recente (com Labaudère, $\mathrm{Ma}$ rienhoff, Celso Antonio Bandeira de Mello) que a exceção possa ser argüida quando a inadimplência da Administração vier criar gravame insuportável para o contratante, excedente da álea normal dos ajustes administrativos".

\section{b. O equilíbrio econômico-financeiro} do contrato.

Mas, as prerrogativas da Administração não podem ser agravadas sem a correspondente compensação, pois "se a Administração Pública quiser pactuar obras, serviços se quiser colaboração do particular, e de Labaudère se refere a isso, a "contratos de colaboração', terá de, certamente, fazer com que o particular se interesse por aquela determinada licitação e, livremente pactue caso seja vencedor ${ }^{138}$

Assim, o interesse do funcionamento do serviço público é compensado pela regra essencial do direito do contratante a uma indenização pelas novas obrigações que the são impostas e que romperam o equilíbrio financeiro do contrato.

Essa contrapartida é essencial: não se sacrificará o direito do contratante. Daí dizer-se que a verdadeira cláusula contratual é a equação financeira, que assegura a comutatividade inerente a todo contrato, estabelecimento proporcional entre encargos assumidos e a remuneração originalmente avencada.

O princípio do equilíbrio econômico-financeiro do contrato garante que a rela- 
ção estabelecida inicialmente pelas partes, entre encargos e retribuição deve ser mantida durante toda a execução do contrato, a fim de que o contratante não sofra uma indevida redução nos lucros normais que pretende obter. Estado Francês e acolhida especialmente no caso Compagnie générale frangaise de Tram ways $^{39}$ de 11.03 .1910

Além da força maior ${ }^{40}$, apontam-se três tipos de áleas ou riscos que o particular enfrenta quando contrata com a Administração ${ }^{41}$

1․ álea ordinária ou empresarial, que está presente em qualquer tipo de negócio. É um risco que todo empresário corre, como resultado da própria flutuação de mercado. Sendo previsível, por ele responde o particular;

$2^{\circ}$. álea administrativa, que abrange duas modalidades:

a) uma decorrente do poder de alteração unilateral do contrato administrativo, par atendimento do interesse público. Por ela responde a Administração, incumbindo-lhe a obrigação de restabelecer o equilíbrio voluntariamente rompido;

b) a outra corresponde ao chamado fato do príncipe, que seria um ato de autoridade, não diretamente relacionado com o contrato, mas que repercute indiretamente sobre ele: nesse caso a administração também responde pelo restabelecimento do equilí brio rompido ${ }^{42}$;

$3^{2}$ álea econômica, que corresponde a circunstâncias externas ao contrato, estranhas à vontade das partes, imprevisíveis, excepcionais, inevitáveis, que causam desequilíbrio muito grande no contrato, dando lugar à aplicação da teoria da imprevisão. Em princípio, repartem-se os prejuízos, já que não decorrem da vontade de nenhuma das partes.

c. Aplicabilidade das teorias da imprevisão

c1. Teoria da imprevisão

A teoria da imprevisão nada mais é do que a revivescência da cláusula Rebus sic
Esta doutrina é aceita pelo Conselho de e da base do negócio jurídico

stantibus, em oposição ao princípio pacta sunt servanda, consagrada em 1916 pelo Conselho de Estado Francês, no caso Cia. de Gás de Bordéus.

Consiste no reconhecimento de que o Estado tem o dever de indenizar a outra parte sempre que haja profunda alteração do equilíbrio econômico-financeiro do contrato, aparecendo primeiro nos contratos administrativos. Pois, se o Estado tem prerrogativas (cláusulas exorbitantes), por outro lado tem o dever de restabelecer as condições materiais para que o outro contratante possa realizar as prestações a que se obrigou e a que se viu impossibilitado de atender em virtude de fatos estranhos à sua vontade. Benoit ${ }^{43}$, em relação aos contratos administrativos, afirma: "Uma vez que eles (os contratantes) estão ambos ligados a uma mesma tarefa de interesse geral, a Administração e seu contratante se apresentam muito menos como dois lutadores, opostos face à face, cada um procurando as fraquezas do outro, como os contratantes do direito privado, do que dois colaboradores, cooperando em uma mesma obra. O contrato admi nistrativo é essencialmente um contrato de colaboração, é para a Administração um meio de recrutar os colaboradores de que necessita".

\section{Evolução da teoria}

No início julgava-se cabível quando "circunstâncias excepcionais, imprevisíveis no momento da conclusão do contrato, e estranhas às partes contratantes, constituíam causa de uma alteração profunda de economia financeira do contrato, levando o outro contratante a realizar a prestação com prejuízo".

Este regime somente era adequado a contratos com prestação duradoura, escalonad no tempo, como nos contratos de fornecimento. A indenização tinha, portanto, fonte extra-contratual, pois provinha de fatos estranhos ao contrato e tinha caráter de ajuda transitória, não correspondendo ao valor integral do prejuízo, visando a auxiliar
Pouco a pouco modifica-se o entendimento, sob a influência das idéias de cola boração e de boa-fé nos contratos administrativos; reconhece-se que há uma constante evolução dos preços, que não há fases de anormalidade para se encontrar uma posterior fase de normalidades. Assim, passou-se a entender que, nos contratos de longa du ração, as partes que ajustaram seus interesses em boa-fé "entendiam de definir no contrato um equilíbrio abstrato de suas relações contratuais, suscetível de ser reformulad em função da evolução econômica. A boa-fé contratual implica, pois, uma readaptação da remuneração global do particular contratante em função da evolução econômica

Conseqüentemente, há o abrandamento do conceito de imprevisão: o imprevisível será somente o que não foi expressamente previsto nas estipulações do contrato.

Rejeitada a concepção da indenização como ajuda financeira temporária, a indenização da imprevisão é, desde então, destinada a manter o equilíbrio financeiro definido quando da conclusão do contrato perdendo o caráter extracontratual para assumir caráter contratual.

c2. Teoria da base do negócio jurídico

No direito francês, aplica-se a teoria da imprevisão aos contratos administrativos, enquanto aos contratos de direito privado se continua a aplicar o princípio da rígid fidelidade ao contrato.

Já no direito alemão, como os contratos de construção de obra pública, de fornecimento ou de concessão de serviço público estão subordinados ao direito privado, em caso de destruição da equivalência econômi co-financeira se aplicam as mesmas regras do direito privado, mesmo que intervenh o Estado.

Para restabelecer a equivalência entre as prestações, elaborou-se a teoria da "base do negócio", desenvolvida inicialmente por Oertmann, e que tem sua origem em duas fontes principais:
- Windscheid, com a teoria da pressuposição ${ }^{44}$ a qual acabou não sendo acolhida pelo $\mathrm{BGB}^{45}$;

do direito inglês com a teoria da impossibilidade objetiva da prestação, de frustração do fim ou de destruição da equivalência entre as prestações.

Segundo Oertmann ${ }^{46}$, deve entender-se por base do negócio "a representação mental de cada uma das partes no momento da conclusão do negócio, conhecida na sua totalidade e não rejeitada pela outra parte, ou a comum representação das diversas partes sobre a existência ou surgimento de certas circunstâncias, nas quais se baseia a vontade negocial".

Acentua, pois, os aspectos relacionados com o conhecimento ou as representações mentais das partes no momento da manifestação ou declaração de vontade. Em ou tras palavras, relacionava-se com os motivo ou pressupostos da vontade: o desaparecimento dos motivos gerava não a nulidade (como no Erro), mas o direito da parte prejudicada a resolver ou a denunciar o contrato.

O objetivo da teoria era o de abranger as hipóteses em que os fatos supervenientes ou frustravam o contrato ou comprometiam gravemente o equilíbrio do vínculo jurídico pela destruição da equivalência entre as prestações, distinguindo dos problemas ligados à vontade nos contratos. O objetivo imediato da teoria era o de resolver os graves problemas decorrentes da $1^{\underline{a}}$ Guerra Mundial.

Após a $2^{\mathbf{a}}$ Guerra Mundial, com o surgimento de mais problemas, Karl Larenz retoma as reflexões de Oertmann, dando-lhe tratamento mais sistemático, distinguindo dois grupos de casos a que se aplicava a teoria:

base objetiva - isto é, conjunto de circunstâncias, conhecidas ou não, dados de fato levados em conta na realização do negócio, constituindo sua base objetiva, independentemente de quaisquer aspectos psicológicos ou ligados à vontade, de tal modo que a alteração dessas circunstâncias implica um desvirtuamento do contrato, não ten- 
do mais "sentido, fim ou objeto" sua subsistência;

- base subjetiva - compreende os casos relacionados com a Vontade, com a pressuposição, com os motivos.

Sob a base objetiva do negócio se agrupam dois $\operatorname{casos}^{47}$ :

$\left.1^{\circ}\right)$ quando a relação, pressuposta no contrato de equivalência das prestacões $s$ destrói de modo tão absoluto que o contrato perde o sentido originariamente estabelecido, de contrato oneroso ou comutativo

$2^{\circ}$ ) impossibilidade de consecução do fim: ocorre quando, embora a prestação seja possível, o resultado por ele colimado é entretanto, impossível de realizar-se, fazendo assim, com que a prestação não tenh "fim ou objeto".

Conclui Larenz $z^{48}$ "o critério decisivo em ambos os casos não é algo alheio ao contrato, como a situação econômica do devedor ou de ambas as partes, mas o sentido e fim do próprio contrato".

Nos contratos bilaterais há sempre um certo equilíbrio entre as prestações estabelecidas. Se as condições econômicas se alteram, a fidelidade do contrato pode representar a inobservância daquilo que as parte convencionaram.

Ex: inflação, a qual transforma o contrato de compra e venda um misto de doação, ato de liberalidade, e compra/venda, ato comutativo, desaparecendo a base do negócio.

Nos casos de destruição da base contratual objetiva e do rompimento da relação de equivalência, as soluções que têm sido adotadas pelo direito germânico são de diferentes ordens, de acordo com Karl Larenz:

a) se a parte ainda não realizou a sua prestação, pode abster-se de fazê-lo até que a outra parte concorde num adequado aumento da contraprestação, que restaura a equivalência;

b) a resolução ou denúncia do contrato;

c) se já se realizou, pode a parte prejudicada, quando não se admita um adequado aumento posterior da contraprestação, reclamar uma indenização, no valor de enriquecimento da outra parte.

\section{Conclusão}

Diferentemente do que ocorre na França, no Brasil a teoria da imprevisão aplica-se indistintamente aos contratos administrati$\operatorname{vos}^{49}$ e aos contratos de direito privado ${ }^{50}$.

Também a teoria da excessiva onerosidade, capaz de destruir a relação de equivalência das prestações, (e portanto, a base objetiva) tem aplicação ${ }^{51}$. Afirma Clóvis do Couto e Silva: "um dos setores mais importantes da aplicação da base objetiva do negócio jurídico é o da alteração das prestações em razão da inflação e também o das modificações resultantes dos atos de Estado de intervenção na economia, como sucede com a fixação dos preços máximos e mínimos ${ }^{52}$."

No direito brasileiro confluem, portanto, as duas tendências, a teoria da imprevisão e a teoria da base do negócio jurídico.

\section{Notas}

1 apud Edmir Netto de Araújo, Contrato Administrativo, RT, pág. 17.

2 Segundo Osvaldo A. B. Mello, "Contrato de Direito Público ou Adminstrativo", RDA vol. 88. pág. 17. "N Alemanha, os autores que atualmente sustentam exist contrato de direito público, afirmam que tem o mesmo efeito jurídico do contrato de direito privado. Então, uma vez firmado, as partes a ele se sujeitam por todo o seu prazo, segundo o ajustado por elas, ante o princípio pacta sunt servianda. Trata-se de contrato público, proclamam, em virtude do seu objeto ser estranho ao próprios das relações entre particulares. Porém, en sendo contrato, o regime jurídico é igual ao de direito privado, e se rege pelas cláusulas com eficácia vinculativa para o futuro."

3 ob. cit., pág. 16

4 "Para a corrente negativista da admissibilidade do contrato nas relações de Direito público, os atos jurídicos por vezes capitulados de contrato mais não são do que a justaposição de dois atos administrativos - um que impõe a prestação, outro que concede a justa indenização" - Marcelo Caetano, Manual de Direito Administrativo, pag. 575

apud Forsthoff, Ernst, Tratado de Derecho Adminstrativo, pág. 374.

6 apud Forsthoff, Ernst, ob. cit., pág. 374

7 Também Fleiner, Fritz, Les Prínciples Générau du droit administratif allemand, pág. 133, afirma que a opinião comum dos autores que negam a existência do contra- to administrativo vê no contrato um título de direito privado, só possivel entre sujeitos iguais.

${ }^{8}$ Criticando esta posição afirma Brewer-Carias "fica claro que a mesma igualdade tão preconizada como base da instituiçáo contratual do Direito Privado nào da essência dos contras. a fira, n" (pa 07) No mesmo sentido Marclo tano, ob. cit., pág. 571 e segs.

"O direito alemão está longe de possuir a contrafig correspondente aos contratos administrativos frat ceses", Forsthoff, Ernst, ob. cit., pág. 377.

10 Segundo Forsthoff, Ernst, ob. cit. pág. 375, en las leyes de expropiación se suele encontrar todo un género contratos de Derecioo público agrupados bajo la común de nominación de contratos de expropiación. Se prevé en ellos la posibilidad de que las partes se pongan de acuerdo sobre la expropiación y la indenización una vez iniciado el proce dimpiento expropiatório.

11 Atribuem para a função pública, assim como para a concessão de serviço público, caráter formalmente contratual. É a posição de Forti, de Artur Lentini, Santi Romano e de Mario Gallo. Conforme Oswaldo A.B. de Mello, ob. cit., pág. 17 .

${ }^{12}$ Garcia de Enterria e Fernández, Tomas-Ramon, Curso de Direito Administrativo, pág. 598.

13 Garcia de Enterria, ob. cit., pág. 600

14 Eduardo Garcia de Enterria, ob. cit., pág. 600

15 O critério material do Serviço Público foi defendid pela Escola de Bordéus. Para Gaston Jèze, o grande personagem da Escola de Bordéus, todo o Direito Administrativo se explica como um Direito especial dos serviços públicos, composto de regras exorbitantes do Direito comum surgidas e impostas por e para a gestão dos serviços públicos. Neste sentido vide Enterria, ob. cit., pág. 601 . Como decorrència do critério substantivo do serviço público, o contrato administrativo não seria lei vinculada e irrevogável para uma das partes, para a Administraçăo, a qual pode impor seu rompimento legitimamente em virtude de seu poder exorbitante de jus variandi, sendo o contrato, portanto, uma instituiçăo essencialmente diferente do contrato privado.

16 Brewer-Carias, Allan R. "Evolução do Conceito de Contratos Administrativos" in RDP, vol. 51-52, pág. 12. 17 O Arrêt Peyrot de 08/07/1963 se relaciona a um contrato subscrito entre duas empresas privadas, uma delas a sociedade de economia mista concessionaria da construção de uma autopista, a propósito de certas obras relacionadas com dita construção. Vide Enterria, Eduardo Garcia, ob. cit., pág. 61

18 ob. cit., pág. 385.

19 ob. cit., pág. 384.

20 ob. cit., pág. 384.

21 Maria Sylvia Zanella Di Pietro, "Direito Administrativo", 3ª edição, págs. 193 a 196.
$22 \mathrm{Na}$ doutrina brasileira se posicionam neste sentido autores como Lúcia Valle Figueiredo (in RDP, vol. 90) que afirma: "inexistem contratos privados da Administraçăo. Existem - isto sim - contratos da Administração Pública, ora sob maior influxo de regras de Direito Privado, ora sob maior influxo das regras de Direito Público". Também Manoel de Oliveira Franco Sobrinho - "no meu entender, apoiado pelas práticas administrativas, tanto faz falar de contratos administrativos, de contratos da administração, ou de contratos com a administração. Tudo se resume numa mesma figura de natureza diversa de antes da ação estatal" (i RDA, vol. 138, pág. 33 a 43).

23 Brewer-Carias, Allan R. "Evolução do Conceito de Contrato Administrativo", RDP 51,52, pág. 6.

24 Para o ente público, a competência.

25 Como por exemplo a necessidade de licitação prévia, somente dispensada $\mathrm{em}$ casos especiais.

26 Cretella Jr., in "Cláusulas de Privilégio nos Contratos Administrativos", RDP 76, pág. 12, critica a denomnação, "cláusulas exorbitantes" afirmando que "denomnar, por exclusão, residualmente, de 'exorbitantes' ou 'derrogatória' determinada cláusula, é atribuir ao direlto civil a posição de matriz do direito administrativo, ou, em outras palavras, e esquecer a categoria juríica, que transcende os dois ramos e imaginar que o arquétipo ou referencial absoluto da árvore jurídica é o jus civile, passando toda construção jurídica a ser elaborada a partir deste importante e mais antigo ramo do Direito". Entretanto, esta è a denominação corrente as cláusulas de privilégio da Administração num contrato administrativo.

27 Elementos necessários de acordo com Marcelo Caeano, ob. cit

28 De acordo com Couto e Silva, Almiro. Parecer CEEE x COEMSA.

${ }^{29}$ Assim, Franco Sobrinho, Manoel de Oliveira, in "Os Contratos Admistrativos na sua existência jurídico-positiva, RDA vol. 138, pág. 36, onde afirma "outro ponto para o qual chamo a atençâo $\mathfrak{e}$ aquele que se refere às chamadas clausulas derrogatórias ou exorbiantes. Não são tais clâusulas que caracterizam qualificando o contrato administrativo. (...) ... o fim, a finalidade, é o essencial na figuração, na conceituação".

30 Conforme Edmir Netto de Araújo, Contrato Administrativo, pág. 50: trata-se do "divisor de águas" entre o contrato de direito privado e o contrato de direito dministrativo, que ainda suscita controvérsias entre os juristas (conforme Georges Vedel, Remanques sur la notion de clause exorbitante, in Mélange Mestre, Sirey, 1956 pág. 527), mas que permite reafirmar a posiçăo de supremacia da Administração dentro do contrato, verticalizando o Estado em relação ao particular contratante e deixando claro que a Administração, ao contratar, não abdica de sua puissance publique, mas, ao contrário, dirige o contrato, fiscalizando os atos do contrário, dirige o contrato, fiscalizando os atos do cedendo-the beneficios, determinando-the procedimen- 
tos, enfim, impondo-lhes sujeições com fundamento no interesse público".

${ }^{31}$ apud Franco Sobrinho, obra e página citados.

32 André de Labaudère, "Do poder da Administração para impor unilateralmente alteraçōes nas cláusulas dos contratos Administrativos", RDA, 37, págs. 48 - 49. 33 ob. cit., pág. 49.

${ }^{34}$ Celso Antonio Bandeira de Mello - "Contrato Ad ministrativo - Inadimplência do Poder Público" - RDA 94 , págs. 284 a 286

35 André de Labadère "Do Poder de Administração para ... ", págs. 63 e segts.

${ }^{36}$ Andre de Labaudére, criticando a posição de doutrinadores que afirmam ser também esta prerrogativa apenas aplicável a alguns contratos administrativos, afirma: "Deve-se, portanto, considerar como princípio geral consagrado pela jurisprudência e não como regra particular a certos contratos e que seria fundada sobre as praxes próprias a esta ou àquela repartição pública, o direito, pertinente à ad ministraçăo, de cancelar, antes do término que pôde ser estipulado e apesar das cláusulas do contrato, a execução deste último." ob. cit., pág. 50.

37" Os contratos da Administração Pública, RDA, vol. 179-180, pág. 83.

38 Lúcia Valle Figueiredo, "Contrato Administrativo Formalidades e Requisitos", in RDP, vol. 90, pág. 132. ${ }^{39}$ Neste caso afirmou o Comissário do Governo Léon Blum: "Em todo contrato de concessão está implicada, como um cálculo, a honesta equivalência entre o que se concede ao concessionario e o que se the exige. E o que se chama a equivalência comercial, a equaçăo financeira do contrato de concessão (apud Eduardo Garia, ob. cit., pág. 654)

${ }^{40}$ Força maior seria o evento exterior, independente da vontade dos contratantes e impeditivo para a execução do contrato. Há, no caso, uma impossibilidade intransponivel, dai porque libera o contratante de sua obrigação. Ex: Greve.

${ }^{41}$ Maria Sylvia Zanella Di Pietro, ob. cit., págs. 207 e segts.

42 Como exemplo cita-se, normalmente, a modificação de leis fiscais ou sociais, que agravam a situação do contratante.

${ }^{43}$ Francis-Paul Benoit, Le Droit Administratif Franģais, Paris, Dalloz, 1968, pág. 588, apud Couto e Silva, Almiro, Parecer CEEE x COEMSA.

44 Windsheid criou o termo "pressuposiçāo" (voraussetzung), definindo-o como um conceito que tinha como fundamento o fato de as partes contratantes fazerem depender o seu acordo, ainda que de modo tácito, da existência de certas situações" apud Clóvis V. do Couto e Silva, "A teoria da base do negócio Jurídico no direito brasileiro pág. 8.

45 Como hem sintetizou Clóvis V do Couto e Silva, b. cit, "O sistema contratual, próprio às con liberais do século XIX, da época em que se realizaram as grandes codificações do Direito Civil, tinha como valor supremo o princípio de autonomia da vontade. Colaborou também para adoção desse princípio, como fundamento único do direito contratual, o fato de as realizações econômicas serem estáveis, sem as grandes crises que começaram a se desenhar na primeira metade do nosso século. Por esse motivo, os códigos não inseriram, expressamente, outros conceitos limitadores da aludida autonomia, como o de cláusula Rebus sic stantibus."

46 apud Couto e Silva, Almiro. Parecer CEEE x COEM-

${ }^{47}$ Karl Larenz, Derecho de Obligaciones, pág. 318.

${ }^{48}$ Karl Larenz, Base del Negocio Jurídico y Cumplimiento de los Contratos, apud Couto e Silva, Almiro, ob. cit.

49 "Em 1963 já se admite ser aplicável a teoria da mprevisão, nas empreitadas de obras públicas para o reajustamento de preços, em determinadas circunstânincidência Martins Cost

50 Arencia...", pag. 44. o Supre Wa tro analisando a recente jurisprudencia do Supremo Trib. Federal e a doutrina, conclui que "nào ha como deixar de reconhecer a aplicação no

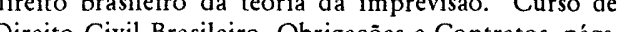
Direito Civil Brasileiro, Obrigaçōes e Contratos, págs. - 172.

51 Orlando Gomes, Transformações Gerais do Direito as Obrigaçôes, 2 ed. , pags. 95 e segts; J.M. Othon Sido. A revisão judicial dos contratos, pág. 39 e 55 . Assim também decisão do Tribunal de Justiça do RS (RT 630/176), relator Adroaldo Furtado Fabricio, que dmitiu a revisão judicial do contrato em razão de modificaçoes das condiçóes económicas causadas pela inflação, as quais haviam alterado a equação econô mio-financeira do negócio jurídico, onerando excessivaA

A citada decisão efetuou, por outro lado, a distinção entre o que é previsivel e imprevisível diante de um processo inflacionário, ou seja, entre o que pode e o que não pode ser levado em conta na avaliação da destruição da base objetiva do negócio jurídico e na aplicação da teoria da imprevisão: "Argumenta a apelante, esgrimindo liçōes doutrinárias respeitabilíssimas quiça incontestáveis em tese, que a teoria da imprevisão năo se pode aplicar à desmonetarização, em qua-

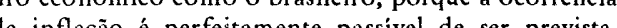

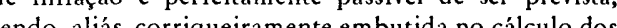
con do com a inflacão e os condicionamentos psicológicos que ela clusão. A inflacão, por certo, ser previsivel quanto à sua ocorrencia a ponto de se fazer inserir em qualquer preço futuro, a ponto de se exagero ditado pela ganância, uma previsao de desvaexagero ditado pela ganância, uma previsão de desvalorização monetária. Entretanto, isso não significa, em previsiveis. Se as condicóes reinantes em determinado momento permitiam supor a permanéncia constante de uma determinada taxa de desvalorizaçáo nos meses futuros, não é de excluir-se, a priori e de modo absoluto, a imprevisão quanto aos indices. Por outras pala vras, previsivel era, por certo, a continuidade da inflção, o imprevisível nas circunstâncias de então era disparada de espiral em ritmo tão descontroladamente ascendente, como veio a ocorrer"

52 Ob. Cit., pág. 10

\section{Bibliografia}

Araújo, Edmir Netto de. Contrato administrativo. São Paulo: Ed. RT. 1987.

Caetano, Marcelo. Manual de Direito Administrativo. Vol. I, Ed. Almeida, Coimbra, 1984

Brewer-Carias, Allan R. Evoluşão do conceito de contrato administrativo. RDP - Vol. 51-52, págs. 6 a 19.

Chaves, Marcos. Contrato administrativo e suas Caract rísticas. RDP, Vol. 78, págs. 110 a 115.

Chase, Luis Enrique da Cunha. Los Contratos de la Administración. RDP. Vol. 59/60, págs. 37 a 45

Costa, Judith H. Martins. A Teoria da Imprevisão e Incidencia dos Planos econônicos governamentais na lasaão contratual. Revista dos Tribunais, Vol. 670 págs. 41 a 48.

Cretella, Jr., J. As cláusulas de privilégio nos contratos administrativos. RDP, Vol. 76, págs. 11 a 27.

Cretella, Jr., J. Negócio Jurídico Administrativo. RDP. Vol. 164 , págs. 29 a 49

Cretella, Jr., J. Direito Administrativo Brasileiro. Rio de Janeiro: Forense, 1983.

Di Pietro, Maria Sylvia Zanella. Direito Administrativo. São Paulo: Atlas, 1992.

Enterria, Eduardo Garcia de Fernández, Tomás-R mon. Curso de Direito Administrativo. Trad. Arnaldo Setti. Ed. RT, 1991, São Paulo.
Ferreira, Sérgio de Andréia. O Reajustamento dos Pregos Contratuais em face do Decreto-Lei $n^{\circ}$ 2.300, RDA, Vol. 167. págs. 22 a 35.

igueiredo, Lúcia Valle. Contrato Administrativo Forma lidades e Requisitos, RDP, vol. 90 , pag. 131 a 137.

Forsthoff, Ernst. Tralado de Derecho Administrativo. Ed. Instituto de Estudios Políticos, Madrid, 1958.

Franco, Sobrinho, Manoel de Oliveira. Os contratos Administrativos na sua existência jurídico-positiva RDA, Vol. 138, págs. 33 a 43.

Labaudère, André de. Do poder da administrasão para impor unilateralmente alterasỗes nas cláusulas dos contratos administrativos. RDA, Vol. 37, págs. 43 a 67.

- Traité tbeórique et pratique des Contrats Administratifs. Vol. I, Ed. Libraire Générale de Droit el de Jurispruden ce, Paris, 1956.

arenz, Karl. Derecho de obligaciones. Trad. de Jaime Santos Briz, Madrid, 1956.

opes, Monica Sette. Contrato administrativo. RDP, vol. 85., págs. 161 a 171.

Mello, Oswaldo Aranha Bandeira de. Contrato de direito público ou administrativo. RDA, vol. 94, págs. 1 a 18. Mello, Celso Antonio Bandeira de. Elementos de Direito Administrativo. São Paulo: Ed. RT, 1991.

Meirelles, Hely Lopes. Direito Administrativo Brasileiro. São Paulo: Ed. RT, 1991.

- Licitação e contrato administrativo. São Paulo: Ed. RT, 1990

Passos, Paulo Roberto da Silva. Cláusula Rebus Sic Stan tibus - Teoria da imprevisão. RT, vol. 647, set/1989.

Pellegrino, Carlos Roberto. "Os contratos da Administração Pública". RDA, vol. 179-180 - págs. 68 a 91. Oliveira, José Carlos Ferreira de. A teoria da Imprevisão e os Contratos Administrativos. RT, vol. 320, págs. 21 a 31. Silva, Clóvis V. do Couto e. A Teoria da Base do Negócio Juridico do Direito Brasileiro. RT - vol. 655, págs. 7 a 11. Silva, Almiro do Couto e. Parecer CEEE x COEMSA. Tello, Roberto. La Teoria de la Imprevision en los Contratos de Derecbo Público. Ed. Libraria Jurídica, Buenos Aires, 1946 